\title{
Purification of Murray Valley Encephalitis Virus
}

\author{
By G. L. ADA, S. G. ANDERSON AND A. ABBOT \\ The Walter and Eliza Hall Institute of Medical Research, Royal Melbourne Hospital \\ Post Office, Victoria, Australia, and The Department of \\ Experimental Medicine, University of Melbourne
}

(Received 27 July 1960)

\begin{abstract}
SUMMARY
Methods are described for the purification of Murray Valley encephalitis virus from baby mouse brain extract. The method finally chosen involved treatment with protamine, ultracentrifugation, adsorption to and elution from hydroxyl apatite and a second ultracentrifugation. The degrees of recovery of virus infectivity and haemagglutinin were about $15 \%$ and $50 \%$, respectively. Measurement of the absorption in the ultraviolet region and examination in the electron microscope suggested that a substantial degree of purification had been achieved. The stability of the infectivity of purified virus was less than that of crude virus. Purified virus yielded infective 'ribonucleic acid' on treatment with phenol. The yield was consistent with the possibility that the potential infective 'ribonucleic acid' in crude virus was contained in infective virus particles.
\end{abstract}

\section{INTRODUCTION}

In 1943 Taylor, Sharp, Beard \& Beard showed that purified preparations of eastern equine encephalomyelitis virus contained protein, lipid and ribonucleic acid. This work provided the first indication that the nucleic acid associated with an animal virus might be entirely of the ribose type. Interest in the composition of these viruses has been stimulated by reports that crude preparations of some viruses in this group, upon treatment with phenol, yielded fractions which appeared to consist mainly of ribonucleic acid (RNA) and were infective (Wecker \& Schäfer, 1957; Cheng, 1958; Anderson \& Ada, 1959). These findings suggest that RNA may carry the genetic information necessary for the production of virus particles which contain lipid as well as nucleoprotein in their structure. The present paper describes a method for purifying Murray Valley encephalitis (MVE) virus from crude extracts of infected baby mouse brains. There was a high recovery rate but the purified virus lost infectivity very rapidly. Nevertheless, it yielded high titre infective 'ribonucleic acid' on treatment with phenol.

\section{METHODS}

Saline. An aqueous solution of $\mathrm{NaCl}(0 \cdot 15 \mathrm{M})$.

Bicarbonate cystine saline $(B C S)$. A solution of $\mathrm{NaHCO}_{3}(0.025 \mathrm{M})$, cystine $(0.85 \mathrm{~mm})$ and $\mathrm{NaCl}(0.15 \mathrm{M})$. The cystine was dissolved in saline by boiling, and after cooling the $\mathrm{NaHCO}_{3}$ was added. The solution was filtered through a Seitz sterilizing pad. 
Veronal cystine saline (VCS). An aqueous solution of sodium barbiturate (0.018 $\mathrm{M}$ ), $\mathrm{HCl}(0 \cdot 009 \mathrm{~N})$, cystine $(0 \cdot 85 \mathrm{mM}), \mathrm{NaCl}(0 \cdot 15 \mathrm{M}) ; \mathrm{pH} \mathrm{7.9}$.

Phosphate buffer. An aqueous solution of $\mathrm{K}_{2} \mathrm{HPO}_{4}(1 \cdot 8 \mathrm{M})$ and $\mathrm{KH}_{2} \mathrm{PO}_{4}(0 \cdot 2 \mathrm{M})$.

Phosphate saline. An aqueous solution containing $\mathrm{NaH}_{2} \mathrm{PO}_{4}(0 \cdot 05 \mathrm{M}), \mathrm{NaOH}$ $(0 \cdot 044 \mathrm{M}), \mathrm{NaCl}(0 \cdot 13 \mathrm{M}) ; \mathrm{pH} 7 \cdot 7$.

Phenol. Phenol (A.R.) was distilled in vacuo, the distillate saturated with glassdistilled water and stored at $0-4^{\circ}$.

Diethyl ether. This cther was prepared as described previously (Anderson \& Ada, 1959).

Normal rabbit serum (NRS). Animals in a laboratory colony were bled from the ear vein and serum separated from the clot at $37^{\circ}$. Sera were pooled and filtered through a Seitz sterilizing pad.

Eggs. White Leghorn/Black Orpington cross eggs were incubated at $39^{\circ}$ until used and thereafter at $36^{\circ}$.

Source of virus. A strain of Murray Valley encephalitis (MVE) virus, isolated in 1951, was used as 8th mouse passage material. It was inoculated intraperitoneally into mice 5 days old and the brains were harvested when the mice were moribund after a further 4 days.

Preparation of virus extract. Infected baby mouse brains were ground in the appropriate solvent by using a glass mortar fitted with a Teflon pestle which rotated at about $\mathbf{4 0 0 0} \mathrm{rev} . / \mathrm{min}$.

Preparation of infective ' $R \boldsymbol{N A}$ '. The standard procedure described previously (Anderson \& Ada, 1959) was slightly modified in that the virus solution was treated twice with phenol, each time for a period of $6 \mathrm{~min}$.

Preparation of normal mouse brain extract. Brains were harvested under chloroform anaesthesia from mice 8 or 9 days old and ground in the desired solvent with the mortar and pestle described above. Grinding was carried out for $3 \mathrm{~min}$. and the fluid clarified by centrifugation $\left(2000 \mathrm{~g}, 5 \mathrm{~min} ., 0-4^{\circ}\right)$.

Titration of virus and infective ' $R N A$ '. Titration in 12-day chick embryos was done on the chorioallantoic membrane, the membranes being 'dropped' with an inoculum of $0.05 \mathrm{ml}$. Titration in mice 5-8 days old was by intraperitoneal inoculation of $0.05 \mathrm{ml}$., or intracerebral injection of $0.01 \mathrm{ml}$. Infectivity endpoints were determined as $50 \%$ lethal end-points at 4 days in chick embryos; mice were observed for deaths over a period of 12 days.

Haemagglutination. Adult goose red cells were prepared in Alsever's solution and stored for periods up to 4 weeks at $4^{\circ}$. Just before use they were washed three times with saline and made up to $1 \%(v / v)$ suspension in phosphate saline. In the haemagglutination test, haemagglutinin was serially diluted in tenfold falling dilutions in $0.5 \mathrm{ml}$. volumes of phosphate saline. To each tube was added $0.25 \mathrm{ml}$. of $1 \%$ goose red cells and the contents mixed. Titrations were read after standing at $22^{\circ}$ for $45 \mathrm{~min}$.

'Fluorocarbon' treatment. A proprietory preparation, labelled Freon 113, was used. Equal volumes of infective solution and fluorocarbon were ground at $0-4^{\circ}$ in the mortar described earlier. After the treatment the aqueous phase was recovered by centrifugation.

Protamine sulphate. A preparation obtained through the courtesy of the Commonwealth Serum Laboratories, Melbourne. 
Hydroxyl apatite. This was prepared according to the technique of Tiselius, Hjertén \& Levin (1956). It was stored under phosphate buffer (0.001 м $\mathrm{K}_{\mathbf{q}} \mathrm{HPO}_{4}$ $\left.0.001 \mathrm{M} \mathrm{KH}_{2} \mathrm{PO}_{4} ; \mathrm{pH} 6.8\right)$ at $0-4^{\circ}$ for periods up to 4 weeks.

Column chromatography. Columns of hydroxyl apatite were prepared about $8 \mathrm{hr}$. before use. They were pre-washed with about $20 \mathrm{ml}$. BCS.

Ultracentrifugation. All ultracentrifugation was carried out in a model L Spinco ultracentrifuge fitted with a $\mathbf{4 0}$ rotor.

Ultraviolet spectrophotometry. A Uvispek apparatus was used, all readings being made in $0.5 \mathrm{~cm}$. optical cells.

Electron microscopy. A Siemens Type E4 electron microscope was used. The infective sample was treated for $16 \mathrm{hr}$. at $4^{\circ}$ with one half its volume of $8 \%(\mathrm{w} / \mathrm{v})$ formaldehyde solution. The sample was then dialysed against distilled water $\left(24 \mathrm{hr} . ; 4^{\circ}\right)$ and mounted from a high-pressure spray gun on formvar covered grids. The droplets were shadowed with gold-manganin and examined at magnifications of about $\times 15,000$ and at $60 \mathrm{kV}$ with a $50 \mu$ objective aperture.

\section{RESULTS}

\section{Preliminary attempts at purification}

In early experiments several techniques were tried for their value in the purification of MVE virus. The criteria of usefulness included the degree of purification achieved, the yield of virus and the subsequent stability of the virus. The techniques were applied to solutions of either crude or partially purified virus, and comprised both those which precipitated non-viral material (treatment with protamine, fluorocarbon or ammonium sulphate) and those which achieved a selective concentration of virus particles (sedimentation or column chromatography).

Treatment with protamine. Warren, Weil, Russ \& Jeffries (1949) found that protamine precipitated non-viral material from crude preparations of virus but did not decrease the infectivity of the solution. They removed excess protamine with heparin. Protamine behaved similarly with crude preparations of MVE virus. In 18 experiments the change in titre varied from a gain of $1.0 \mathrm{log}$ unit to a loss of $1.0 \mathrm{log}$ unit of infectivity, the mean change being a loss of $0.1 \mathrm{log}$ unit which was not significant. Protamine treatment decreased the u.v. absorption at $260 \mathrm{~m} \mu$ and $800 \mathrm{~m} \mu$ by an average of $80 \%$ and $90 \%$, respectively. The method of purification finally chosen included treatment with protamine but not heparin.

Treatment with fluorocarbon. Gessler, Bender \& Parkinson (1956) found that some fluorocarbons when mixed vigorously with crude preparations of certain viruses preferentially removed non-viral material from solution. In the present work, some purification was achieved when MVE virus preparations were briefly treated with fluorocarbon. The best results were obtained when infected fluids, previously treated with protamine, were exposed to fluorocarbon for $5 \mathrm{~min}$. No loss of infectivity occurred, though the \% decrease of absorption at $260 \mathrm{~m} \mu$ and $300 \mathrm{~m} \mu$ was $26 \pm$ 14 (s.D.) and $45 \pm 15$ (s.D.), respectively. When virus, which had been purified either by sedimentation in the ultracentrifuge or by ammonium sulphate fractionation as described below, was treated with fluorocarbon, the recovery of infectivity was very erratic.

Ammonium sulphate fractionation. Crude preparations of virus were first treated 
with protamine, then with fluorocarbon, and finally with ammonium sulphate. In six experiments the mean loss of infectivity due to the ammonium sulphate step was $0.7 \log \pm 1.2 \log$ unit. In a seventh experiment, dialysis against buffered saline (pH $7 \cdot 7$ ) at $0-4^{\circ}$ for $16 \mathrm{hr}$. to remove ammonium sulphate, resulted in a further loss of $1.3 \log$ unit. This dialysed material lost another $1.4 \mathrm{log}$ unit of infectivity after one fluorocarbon treatment.

Adsorption to and elution from hydroxyl apatite. The virus present after treatment of crude preparations with protamine could be adsorbed to columns of hydroxyl apatite. In preliminary experiments, $30 \mathrm{ml}$. protamine-treated extract were adsorbed to a column $(3 \mathrm{~cm} . \times 1.5 \mathrm{~cm}$.) of hydroxyl apatite which was then developed with a gradient of phosphate concentration $(0.02 \mathrm{M-2} \cdot 0 \mathrm{M})$. The virus eluted under these conditions and the infectivity were quantitatively recovered. However the elution profile was very broad and, though marked purification occurred, little concentration was achieved. Later work showed that by using a deposit obtained by centrifugation of the protamine-treated extract, a smaller capacity column could be used and a sharper elution pattern obtained.

Ultracentrifugation. Virus in eluates from hydroxyl apatite columns could be sedimented by ultracentrifugation. In four experiments, high titre eluates were pooled and centrifuged at $90,000 \mathrm{~g}$ for $30 \mathrm{~min}$. and the rotor then stopped with the brake on. The virus formed a firm pellet at the bottom of the tube. About $95 \%$ of the supernatant fluid was removed by Pasteur pipette and the remainder used for resuspending the virus pellet. In four experiments the average recovery of virus was $100 \%, 90 \%$ being in the sediment. When such virus was again centrifuged under the same condition the pellet was not adequately dispersed and the recovery of infectivity was appreciably lower. In the technique finally adopted the conditions of centrifugation were changed in order to overcome this difficulty.

\section{Adopted procedure for purification of $M V E$ virus}

The choice of a standard procedure was governed not only by the yield of virus and the degree of purification achieved but also by the lability of the purified virus. Because of this it was desirable that concentration should be accompanied by purification; therefore after protamine treatment the virus was concentrated by sedimentation in the ultracentrifuge. This had the advantage of removing much of the soluble protein so that a smaller column of hydroxyl apatite could be used. The complete procedure took about $6 \mathrm{hr}$, and all steps were carried out between 0 and $4^{\circ}$. Sterile reagents and containers were used.

Sixty freshly-harvested infected mouse brains were ground in $90 \mathrm{ml}$. BCS and the solution clarified by centrifugation at $2000 \mathrm{~g}$ for $5 \mathrm{~min}$. Ten $\mathrm{ml}$. of a warm saline solution containing $\mathbf{3 6 0} \mathrm{mg}$. protamine sulphate was added with stirring to the supernatant fluid (termed 'original extract'). The mixture was shaken mechanically (oscillation $/ \mathrm{min} .=100$; amplitude $=5 \mathrm{~cm}$.) for $30 \mathrm{~min}$. after which a clear supernatant fluid (protamine-treated extract) was obtained by centrifugation $(2000 \mathrm{~g} ; 10 \mathrm{~min}$.$) . The protamine-treated extract was centrifuged in a 40-rotor at$ $93,000 \mathrm{~g}$ for $15 \mathrm{~min}$., the brake being left off to slow deceleration. The virus was seen as a loose milky concentrate at the bottom of the tube with a small clear pellet to one side. The supernatant fluid was carefully removed, leaving about 
$0.5 \mathrm{ml}$. in which the virus was readily resuspended with a Pasteur pipette (termed 'deposit 1 ').

The pooled deposits (about $5 \mathrm{ml}$.) were applied to a column $(2 \mathrm{~cm} . \times 1 \mathrm{~cm}$.) of hydroxyl apatite and the column washed with $10 \mathrm{ml}$. BCS. The column was then developed with about $5 \mathrm{ml}$. portions of BCS to which $2 \mathrm{M}$ phosphate buffer ( $\mathrm{pH} \mathrm{7 \cdot 7)}$ had been added to yield final concentrations of $0.025 \mathrm{M}, 0.05 \mathrm{M}, 0.1 \mathrm{M}, 0.2 \mathrm{M}, 0.8 \mathrm{M}$, $0.4 \mathrm{M}$ and $0.5 \mathrm{M}$ phosphate. The flow rate was about $15 \mathrm{ml} . / \mathrm{hr}$.

The $0.1 \mathrm{M}$ and $0.2 \mathrm{M}$ eluates were pooled and centrifuged $(98,000 \mathrm{~g}, 12 \mathrm{~min}$.). The sedimented virus was then seen as before and was resuspended with a Pasteur pipette in about $0.7 \mathrm{ml}$. of the supernatant fluid. The products thus obtained were termed 'supernatant 2 ' and 'deposit 2 '.

\section{Evaluation of standard procedure}

The standard procedure for purification was applied to nine crude preparations of virus. The various fractions were examined for their \% recovery of virus. as estimated by haemagglutination, infectivity, and u.v. absorption. The latter examination also gave some indication of the chemical nature of each fraction.

Recovery of viral haemagglutinin. The original extracts showed haemagglutination in only five of the nine samples; in these five the titres ranged from 2500 to 4000. All this haemagglutinin was recovered between the $0.1,0.2$ and $0.8 \mathrm{M}$ phosphate eluates, and in four of the five cases the haemagglutinin was present almost entirely in the 0.1 and $0.2 \mathrm{M}$ fractions. There was again a quantitative recovery of haemagglutinin in supernatant fluid 2 and in deposit 2, the distribution between these two fractions being in the ratio $1: 8 \cdot 4$. In four out of five experiments, the haemagglutinin titre of deposit 2 was between $2 \times 10^{5}$ and $4 \times 10^{5}$.

In those experiments where it was sought, an inhibitor of haemagglutination was found in some fractions. The inhibitor was not titrated in the classical fashion, but some estimate of its amount was obtained by noting the extent of the prozone in a standard titration of haemagglutinin. This prozone extended to the dilutions $1 / 200,1 / 200$ and 1/300 in titrations of three original extracts, with haemagglutinin titres of 3000,8000 and 4000 , respectively. A prozone occurred irregularly in the $0.1 \mathrm{M}$ to $0.5 \mathrm{M}$ eluates; in those $0.1 \mathrm{M}$ and $0.2 \mathrm{M}$ eluates where the prozone occurred, it extended to dilutions of 100 to 3000 ; in the $0.3 \mathrm{M}$ to $0.5 \mathrm{M}$ eluates, to dilutions of 5 to 30 . In five experiments the 'titre' of prozone ranged from 10 to 300 in supernatant 2, and in three experiments from 20 to 80 in deposit 2.

It was felt that if sufficient inhibitor were present it might completely obscure haemagglutinin. This was accepted as the explanation of the absence of detectable haemagglutinin in four of the nine original extracts. Four of the nine $0.025 \mathrm{M}$ eluates and five of the $0.05 \mathrm{M}$ eluates also lacked haemagglutinin although the infectivity titres were such that considerable haemagglutinin titres would have been expected. Here too the effect was attributed to an excess of inhibitor.

These experiments throw little light on the nature of the inhibitor(s) of haemagglutinin. In one experiment, normal baby mouse brains were extracted and subjected to the standard fractionation procedure. The ability of the fractions to inhibit viral haemagglutination was tested, the haemagglutinin used being a $0.3 \mathrm{~m}$ phosphate 
eluate prepared on the same day. This had a titre of 4000 and was used at a dilution containing 12 A.D. The original extract was found to have an inhibitor titre of 60; none of the other fractions had any activity.

\section{Recovery of infectivity}

In nine experiments the ELD50 of the original extract from infected brain had a mean value of $8 \cdot 2 \mathrm{log}$. (range $7 \cdot 6-8 \cdot 7$ ). In five experiments the average recovery of infectivity in different fractions was as follows: deposit 1, $71 \%$; effluent, usually less than $0.001 \%$; eluate $0.025 \mathrm{M}, 2 \%$; eluates $0.1 \mathrm{M}+0.2 \mathrm{M}, 70 \%$; eluates, $0.3 \mathrm{M}+$ $0.4 \mathrm{M}+0.5 \mathrm{M}, 6 \%$; supernatant 2, $5 \%$; deposit 2, $15 \%$. Most of the infectivity was recovered in the $0.1 \mathrm{M}$ and $0.2 \mathrm{M}$ eluates which were therefore chosen for final centrifugation. The greatest loss was during the final centrifugation.

The ratio of ELD50 to haemagglutinin titre was calculated for certain fractions in three of the experiments where haemagglutinin was present in the original extract. Mean values were: the original extract, $3.4 \times 10^{4}$; deposit $1,1.1 \times 10^{4}$; the $0.025 \mathrm{M}$ eluate, $>20 \times 10^{4}$; the $0.1 \mathrm{M}+0.2 \mathrm{M}$ eluates, $1.5 \times 10^{4}$; the $0.3 \mathrm{M}+0.4 \mathrm{M}$ eluates, $0.2 \times 10^{4}$; deposit $2,0.6 \times 10^{4}$. The ratio for original extract and for combined $0.1 \mathrm{M}$ and $0.2 \mathrm{M}$ eluates were similar. The high value for the earlier eluate was attributed to the suppression of haemagglutinin by inhibitor; the low value for the later eluates was attributed to dead haemagglutinating virus, a hypothesis which is supported by the low ratios of ELD50 to u.v. absorption values of these eluates. It was first thought that concentrations of phosphate higher than $0.2 \mathrm{M}$ might destroy infectivity but the addition of phosphate to $0.2 \mathrm{M}$ eluates was found not to decrease the ELD50 value.

U.v. absorption. In Table 1 are recorded the absorption of fractions from normal and from infected brain extracts at $260 \mathrm{~m} \mu$ and values of the ratio, absorption at $260 \mathrm{~m} \mu$ : absorption at $280 \mathrm{~m} \mu$. In both cases the values quoted were from single experiments. The results from the experiment with infected brain were typical of 5 experiments. As seen in columns 1 and 2 of Table 1, the normal brain absorbed more than the infected brain extract. The protamine extracts of each preparation absorbed to about the same degree. Deposit 1 derived from the infected extract absorbed more than did deposit 1 from the normal extract, because of the presence of virus in the former. The effluent from each column showed similar degrees of absorption. A substantial difference in the elution profile from the infected column compared with the normal column was first apparent at the $0.1 \mathrm{M}$ eluate stage. This and later eluates from the normal column contained negligible amounts of material absorbing at $260 \mathrm{~m} \mu$, whereas in the infected column these were the very eluates where there was an accumulation of virus. The peak was in the $0.2 \mathrm{M}$ eluate consistently in nine experiments. This effect was seen visually in eluates from the infected column, the $0 \cdot 2 \mathrm{M}$ eluate having a greater opacity than the $0 \cdot 1 \mathrm{M}$ and $0.3 \mathrm{~m}$ eluates. The other fractions were clear, as were all eluates from the normal column.

Of the substances likely to be present in appreciable amounts in the fractions, only three absorbed well at $260 \mathrm{~m} \mu$ and $270 \mathrm{~m} \mu$ : namely, proteins and nucleoproteins and small molecular weight purine and pyrimidine derivatives. For each of these, the ratio $260 \mathrm{~m} \mu: 280 \mathrm{~m} \mu$ lay in a typical range; for proteins, it was less than 1 ; for nucleoproteins, 1 to 2 , and for small molecular weight purine and pyrimidine 
Table 1. Ultraviolet absorption values of fractions from normal and from $M V E-$ infected brains, and the infectivity titres of fractions from infected brains

Values were from one experiment.

\begin{tabular}{|c|c|c|c|c|c|c|c|}
\hline & & & OD 2 & $\mathbf{m} \mu^{*}$ & OD $260 \mathrm{~m} \mu$ & OD $280 \mathrm{~m} \mu$ & Infec- \\
\hline Frac & tion & (ml.) & Normal & Infected & Normal & Infected & $\left(\log _{10}\right)$ \\
\hline Original & extract & 90 & $28 \cdot 4$ & $14 \cdot 4$ & $1 \cdot 26$ & $1 \cdot 22$ & $8 \cdot 3$ \\
\hline Protami & ne extract & - & $1 \cdot 80$ & 1.92 & 1.83 & 1.84 & $8 \cdot 2$ \\
\hline Deposit & & - & $2 \cdot 44$ & 8.24 & 1.98 & 1.58 & 9-4 \\
\hline Column & effluent & 一 & 0.74 & $0 \cdot 61$ & $2 \cdot 15$ & $2 \cdot 4$ & 4.4 \\
\hline & 0.025 & $\mathbf{5}$ & 0.097 & $0 \cdot 109$ & $1 \cdot 12$ & 1.07 & $7 \cdot 0$ \\
\hline & $0 \cdot 05$ & 5 & 0.091 & 0.113 & 0.86 & 0.83 & $7 \cdot 5$ \\
\hline Column & 0.1 & $\mathbf{5}$ & 0.087 & $0 \cdot 238$ & $0 \cdot 68$ & $\mathbf{1 \cdot 3 4}$ & $8 \cdot 2$ \\
\hline eluates & 0.2 & 5 & 0.087 & 0.579 & 0.78 & $\mathbf{1 . 8 8}$ & $9 \cdot 2$ \\
\hline (M) & $0 \cdot \mathbf{3}$ & 5 & 0.01 & 0.212 & - & $\mathbf{1} \cdot \mathbf{8 7}$ & $8 \cdot 6$ \\
\hline & 0.4 & 5 & 0.01 & 0.081 & - & - & $8 \cdot 2$ \\
\hline & 0.5 & 5 & 0.01 & 0.01 & - & - & - \\
\hline Superna & $\tan t 2$ & $9 \cdot 3$ & - & $0 \cdot 132$ & - & $1 \cdot 18$ & $8 \cdot 2$ \\
\hline Deposit & & 0.7 & - & 4.42 & - & 1.56 & $9 \cdot 6$ \\
\hline
\end{tabular}

derivatives, it was greater than 2. The latter compounds were not deposited under the conditions of the present experiments. As about $70 \%$ of the absorbing material in the $0.1 \mathrm{M}$ and $0.2 \mathrm{M}$ eluates was sedimented and as the remaining $25 \%$ (supernatant 2) had a ratio of $1 \cdot 18$, it seemed that small molecular weight purine and pyrimidine derivatives were virtually absent; the sedimented material with a ratio of 1.56 was therefore largely nucleoprotein. The value of the $260 \mathrm{~m} \mu: 280 \mathrm{~m} \mu$ ratio of the $0.1 \mathrm{M}$ and $0.2 \mathrm{M}$ eluates was higher in the 'infected' column (average 1.36) than in the control column (average 0.73); this difference was mostly due to nucleoprotein.

\section{Properties of purified virus}

The properties of deposit 2 were investigated in four ways: u.v. absorption and studies in the electron microscope indicated substantial purity; the purified virus yielded infective 'RNA', but was less stable to heat than was crude virus.

Ultraviolet absorption spectrum. An average absorption curve was calculated from the values for eight preparations of deposit 2 . The resulting curve was typical of nucleoproteins. The value of the ratio, $260 \mathrm{~m} \mu: 280 \mathrm{~m} \mu$, was $1 \cdot 48 \pm 0 \cdot 06$.

Examination in the electron microscope. Plate 1, a micrograph of deposit 2, shows little else in the preparation but virus particles.

Liberation of infective ' $R \boldsymbol{N A}$ ' from purified virus preparations. In three experiments infective 'RNA' was made by phenol treatment of original extract and of deposit 2. For this purpose original extract was diluted $1 / 10$ and the final deposit was diluted 1/1000 in normal baby mouse brain extract before phenol treatment; these dilutions were allowed for in the final calculation. The ratio of virus titre to titre of ' $R N A$ ' derived from that virus ( $V: R$ ratio) was $2 \cdot 3,2 \cdot 4$ and $3 \cdot 6 \log$ (average $2 \cdot 8$ ) for the three original extracts and $2.0,3.0$ and 3.4 log (average 2.8 ) for the three corresponding preparations of deposit 2. 
Stability studies. The best diluents for crude virus were earlier found to be NRS $(10 \%, v / v)$ and mouse brain extract (Anderson \& Ada, 1959) in which the virus was comparatively stable. Both crude virus in the form of original extract and purified virus in the form of deposit 2 were diluted $1 / 100$ in NRS $(10 \%, v / v)$ and held at $37^{\circ}$. Infective titres were, for crude virus, at $0 \mathrm{~min} ., 8 \cdot 1 \log$; at $15 \mathrm{~min}$., $8.1 \mathrm{log}$; at $60 \mathrm{~min}$., 8.0 log. For purified virus, at $0 \mathrm{~min} ., 9.0 \mathrm{log}$; at $15 \mathrm{~min}$., $9.8 \mathrm{log}$; at $60 \mathrm{~min} ., 8.8 \mathrm{log}$. This increase in titre after $15 \mathrm{~min}$. was found regularly. In one experiment of this type where infectivity titrations were done in triplicate, the average values for purified virus were at $0 \mathrm{~min} ., 9 \cdot 2 \mathrm{log}$; at $7 \frac{1}{2} \mathrm{~min} ., 9 \cdot 4 \mathrm{log}$ and at $15 \mathrm{~min} .9 .6 \mathrm{log}$. End-points in the titration of samples incubated 30 or $60 \mathrm{~min}$. were very close but appeared to indicate a decrease in titre.

Purified virus was less stable in the absence of NRS. It lost infectivity when held at $37^{\circ}$ either undiluted or diluted $1 / 1$ in VCS. Typical figures in the latter diluent were, at $0 \mathrm{~min}$., $8.5 \mathrm{log} ; 30 \mathrm{~min}$., $7 \cdot 2 \mathrm{log}$ and at $60 \mathrm{~min}$., less than $6.2 \mathrm{log}$. However, in this diluent, at $20^{\circ}$, virus lost only $0.4 \log$ of infectivity over a period of $60 \mathrm{~min}$.

\section{DISCUSSION}

The outstanding impression from the present work was the ease with which semipurified or purified MVE virus lost infectivity. It was not clear whether this was a reflexion of an intrinsic instability of pure virus or whether it was due to damage caused by the method of purification. The diluent in which pure virus was least unstable was a 1/10 dilution in normal rabbit serum. When diluted in this medium and held at $37^{\circ}$ pure virus showed an initial increase in titre and then a slow decay. The early increase of about $0.5 \mathrm{log}$ may have indicated the resurrection of individual virus particles, but was probably due to the disaggregation of clumped virus. The later decay was attributed to instability of virus.

The instability of purified virus made it difficult to assess virus recovery rates during purification. Through the first part of the purification procedure (from original extract to the combined $0 \cdot 1 \mathrm{M}$ and $0.2 \mathrm{M}$ eluates) there was an average recovery of $70 \%$ of infective virus. Through the second part of the purification procedure (from eluates to final deposit) infectivity was decreased by $\mathbf{7 3} \%$ but haemagglutinin was not lost at all, and the u.v. absorption results also pointed to a satisfactory recovery of viral material during this phase. It thus seemed that most of the original virus was recovered in deposit 2 , and that the final yield was vitiated only by the instability of the infectivity of the purified virus.

The purity of deposit 2 has been estimated both by electron microscopy and by examination in the ultraviolet spectrophotometer. The results of electron microscopy were more easily interpreted, and the pictures left little doubt that virus-like particles comprised most of the material in deposit 2.

From the u.v. absorption pattern it was not possible to determine accurately the degree of purity, but the results were consistent with the belief that deposit 2 was relatively pure virus. First, a comparison of the u.v. absorption profiles of eluates from infected columns and from normal columns suggested that nearly all of the absorbing material in the $0.1 \mathrm{M}$ and $0.2 \mathrm{M}$ phosphate eluates from the infected column was virus, and the small amounts of soluble protein present in these fractions would have been largely eliminated during the final centrifugation. Secondly, the value 
of the ratio, O.D. $260 \mathrm{~m} \mu$ :O.D. $280 \mathrm{~m} \mu$ for 8 preparations of deposit 2 was relatively constant $(1 \cdot 48 \pm 0 \cdot 06)$. These are the wavelengths of maximum absorption of nucleic acid and protein, respectively, and an alteration in the relative concentrations of these two components between one preparation of deposit 2 and another would have resulted in a substantial change in this ratio. Such a change was not observed and the constancy was taken to indicate that deposit 2 contained mainly one type of particle. Thirdly, the absolute value of this ratio (1.48) was consistent with the major component being nucleoprotein in character.

Some estimate of the degree of purification achieved was obtained from the value of the ratio of haemagglutinin to u.v. absorption. This was 700- to 1100-fold higher for deposit 2 than for the crude brain extract. Although the estimate of the u.v. absorption of the crude extract was unduly high because of light scattering effects, it was concluded that the above ratio meant that a better than 500 -fold purification had been achieved.

An obvious next step would have been to determine the number of virus particles per infective unit of purified virus preparation. Many such attempts were made in this laboratory, but all were unsuccessful because of the failure to obtain suspensions consisting mostly of single particles for electron microscopy.

It was found earlier that treatment of crude MVE virus with phenol gave rise to infective 'RNA' (Anderson \& Ada, 1959). A prime reason for developing a method of purifying MVE virus was to see whether phenol treatment of pure virus liberated ' $\mathbf{R N A}$ ' and whether the potential ' $\mathbf{R N A}$ ' in crude preparations was present only in mature virus particles. The average value of the ratio, infectivity of virus: infectivity of 'RNA' ( $\mathrm{V}: \mathbf{R}$ ) was $2 \cdot 8$ for both crude and purified preparations. However, the constancy of this ratio may be misleading. It was indicated above that the infectivity of deposit 2 was lower than was expected from its haemagglutinin titre and optical density. As it was not known whether this loss of infectivity was due to damage to protein, lipid or nucleic acid (see Ada \& Anderson, 1959) it was difficult to know the meaning of a value of $2 \cdot 8$ for the $V: R$ ratio. For this reason and because of the batch variation in $V: R$ ratios, it is not possible to state whether all the potential ' $R N A$ ' in crude virus preparations is contained in mature virus particles. Nevertheless, it is clear beyond reasonable doubt that purified MVE virus yields infective 'RNA'; the figures were not inconsistent with the idea that the potential infective ' $R N A$ ' in crude preparations derived from mature virus.

This work was supported by a grant from the National Health and Medical Research Council of Australia.

\section{REFERENCES}

ADA, G. L. \& ANDERson, S. G. (1959). Yield of infective 'ribonucleic acid' from impure Murray Valley encephalitis virus after different treatments. Nature, Lond. 183, 799.

AnDerson, S. G. \& ADA, G. L. (1959). Murray Valley encephalitis virus: preparation of an infective 'ribonucleic acid' fraction. Aust. J. exp. Biol. med. Sci. 37, 353.

Cheng, P. Y. (1958). Infectivity of ribonucleic acid from mouse brains infected with Semliki forest virus. Nature, Lond. 181, 1800.

Gessler, A. E., Bender, C. E. \& Parkinson, M. C. (1956). Animal viruses isolated by fluorocarbon emulsification. Trans. N.Y. Acad. Sci. 18, 707. 
TaYlor, A. R., Sharp, D. G., Beard, D. \& Bfard, J. W. (1948). Isolation and properties of the equine encephalomyelitis virus (Eastern strain). J. infect. Dis. 72, 81 .

Tiselifus, A., Huentén, S. \& Levin, Ö. (1956). Protein chromatography on calcium phosphate columns. Arch. Biochem. Biophys. 65, 132.

Warren, J., WeIn, M. L., Russ, S. B. \& Jerrrme, H. (1949). Purification of certain viruses by use of protamine sulphate. Proc. Soc. exp. Biol. Med., N.Y. 72, 662.

WECKER, E. \& ScHÄFER, W. (1957). Eine infektiöse Komponente von Ribonucleinsäurecharakter aus dem Virus der amerikanischen Pferdeencephalomyelitis (Typ Ost). Z. Naturforsch. $12 b, 415$.

\section{explanation OF PLATE}

Electron micrograph of purified Murray Valley encephalitis virus. Shadowed with gold manganin. Magnification $\times 40,000$. 


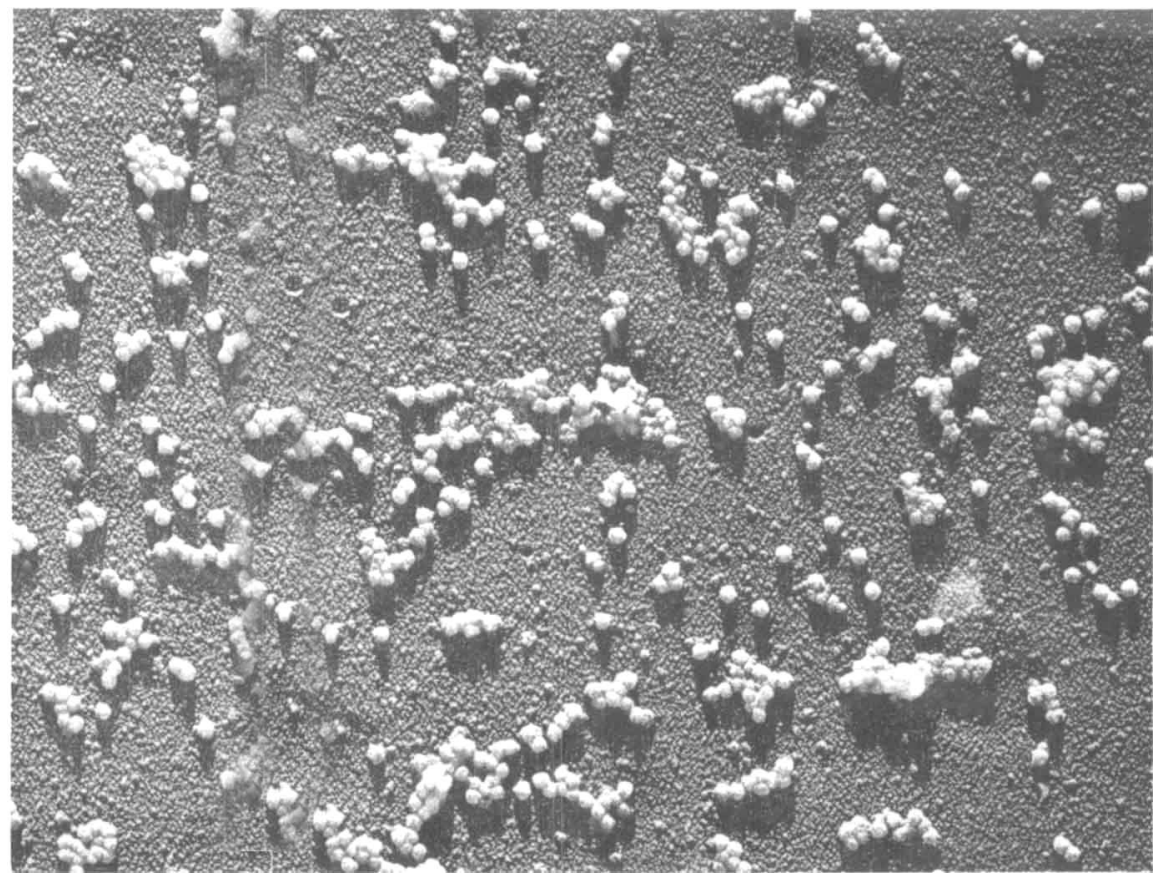

